\title{
The Implementation of the Rights of Suspects in Detention Process
}

\author{
Ruslan Ranggong (Corresponding author) \\ Lecturer " 45 " University of Makassar, Indonesia \\ E-mail: ruslanranggong@yahoo.co.id
}

Received: July 18, 2013 Accepted: August 27, 2013 Published: November 28, 2013

doi:10.5296/ijssr.v2i1.4634 URL: http://dx.doi.org/10.5296/ijssr.v2i1.4634

\begin{abstract}
Detention is a forceful effort taken to confine freedom in the movement of a suspected person committing a crime in the aim of accelerating criminal justice. However, it does not mean that prisoners whose liberty is confined can be treated arbitrarily in the form of torture, cruel treatment and discrimination. This study aims at observing the implementation of the rights of suspects for not being tortured and cruelly treated in the detention process and the obstacles in the implementation of these rights. The findings shows that this kind of implementation has not been optimally realized as torture practice and cruel treatment due to the weak understanding of law instruments against torture and arrogance of the legal officials are still found.
\end{abstract}

Keywords: implementation, rights of suspects, detention

\section{Introduction}

Human rights which are natural remain attached to each person under any circumstances, including a person undergoing detention. Removing and eliminating human rights is equal to eliminating human existence as God's creation. Human Rights based on C. De Rover (2000: 47) may be broken, but it cannot be eliminated.

The rights to freedom from torture as a part of the civil and political rights is defined in the ICCPR Covenant ratified by Act No. 12 of 2005, while the Convention against Torture was ratified earlier with the Law No. 5 of 1998. Regardless the assumption that the second ratification of international legal instruments was issued due to the strong pressure from NGOs, both foreign and domestic, the ratification has shown that the government has the will to prevent and eradicate torture practices that potentially accompany the process of arrests and detention. 
The prohibition of torture against those who are inspected in the criminal justice process in Indonesia has basically had a legal basis. Therefore, the mandate of Article 4 of the Convention against Torture which requires each state to include the prohibition of torture into national legislation has been met. It can be found in Section $28 \mathrm{G}$ Constitution of State of Republic of Indonesia of 1945 which states that everyone has the rights to freedom from torture or degrading treatment of human dignity and the rights to obtain political protection from other countries. It is also clearly stated in Article 33 section (1) Human Rights Law that everyone has the rights to freedom from torture, cruel, inhuman, or degrading treatment or punishment.

Detention as a forceful effort cannot remove or ignore the dignity and prestige of a detainee as a human being whose rights are protected by law and the state. Suspects imposed detention must be protected and placed in a position equal before the law and be protected from all forms of arbitary treatment such as torture, cruel treatment and discrimination.

The raid of Cebongan Prison that killed four prisoners is just one of various practices of torture against detainees. In various regions, such practices are still common although not as chaotic as the raid of Cebongan Prison. For example, torture faced by Adil, a detainee of Police Resort Pare-Pare South Sulawesi, by police officers in the detention room resulting in injuries of his mouth makes the two front teeth almost barely loosen (Fajar, 2007). Similarly, the act of multiple sexual abuses by unscrupulous Chief of Police Sector of Central Tomohon North Sulawesi, AKP. ST, Kanit Reskrim AIPDA. AR and BRIPTU. FK against a woman named YR was detained at the police station (Bisnis Jakarta, 2007). A case of torture against a woman named Sriyati by an officer of Correctional Institution of Ponorogo East Java (Metro TV, 2007).

Based on the previous discussion, the issues examined in this study are formulated as follows: (1) How suspects' rights to freedom from torture and cruel treatment in detention process?, and (2). What are the practical obstacles and challenges to their effective implementation?. Therefore, the aims of this study are: (1) Observing the implementation of suspects' rights to freedom from torture and cruel treatment in criminal proceedings, and (2) Finding practical obstacles and challenges to their effective implementation.

\section{Methodology of the Study}

The study was conducted in Makassar, South Sulawesi Province. It is a normative study supported with empirical data. The population of the study covered investigators, prosecutors, judges, lawyers, detention house/prison officials, prisoners and families of prisoners. Sample was selected by stratified random sampling conducted by arranging stratified respondents with total respondents of 50 people. Data sources covered primary data were obtained directly from respondents through questionnaires and interviews, while secondary data were obtained through literary study. 


\section{Results and Discussion}

Findings showed that $53.3 \%$ of the respondents stated that the rights to freedom from torture were less implemented which was shown in the findings of torture practices against detainees. Moreover, $31.2 \%$ of the respondents judged that rights to freedom from torture had been implemented while $15.5 \%$ respondents stated it had not been implemented yet.

Majority respondents judged that tortures against prisoners are still found but progressively decreasing, it was confirmed by investigator respondents (interview, April 15 2013). They did not deny that torture against detainees within certain limits still exist especially during the investigation process in order to get information or against recalcitrant prisoners in the cells who disturb other prisoners or disobey the prevailing regulation in the prison. However, torture is rarely the case today as the increasing professionality among members of the police and the tight supervision of officials and the public through the mass media.

Information from investigator respondents is also in line with the statement of the legal advisor respondents (interview, April 20,2013), which stated that practice of torture against detainees still there, especially in the process of investigation or in the detention house. Torture against detainee during investigation is very likely to happen especially if the detainee is not supported by a legal advisor, so that at the time of direct inspection, the detainee sits face to face with the inspector.

The statement of majority respondents were also justified by an informant, torture is still there but progessively dreasing. It was also supported by cases of torture experienced by Hendra Purwanto and Ramli aka Culla who are still 11 years old. Both were tortured by two members of the Police Sector of Ujung Loe Bulukumba using wood and a water hose in order to confess the alleged acts. Similarly, the cases of violence by prison officer Class II A Palopo against Kusnadi, a prisoner entrusted to the State Attorney of Palopo. As a result of the violence, Kusnadi experienced battering all over his body and should be taken care in hospital. The cause of the violence was simply because he gave wrong answer to the prison officers.

Linking both of the torture cases by police or prison officials with definition in the Convention Against Torture and articles of torture in Indonesian Criminal Code, such practices can be categorized as a form of torture and mistreatment against detainee. The case is even worse if the victim of torture and inhumane treatment are child detainee. Children Rights Convention (CRC) has determined:

- Child torture and molestation are banned:

- Repeal of child freedom against law and arbitrary treatment are prohibited;

- Children deprived of their liberty shall be treated with humanity and respect for the dignity of humanity in a way that considers the special personal needs according to their age;

- Child detainees are separated with adult detainees; 
- Child detainees have the right to maintain contact with their families, to be given immediate access to get legal advice, and to challenge the validity of their detention before a court or other authority.

In relation with the definition of torture as defined in the Convention against Torture, perpetrators of mental abuse must also be punished. Criminalization of mental torture is reasonable because it can have serious effect on the psychological development of the victims. Cases of suicide or reckless act of detainees are strongly correlated with heavy mental depression during criminal proceedings. In this study, researcher found that $60 \%$ of prisoner respondents who claimed of obtaining mental pressure due the treatment of the apparatus which are usually in the form of tortures, insults and bullies or treats to be detained for a long time.

Based on the findings, it was obtained datawhich showed that $63 \%$ of respondents stated that factorcausing torture against detainee is arrogance of the apparatus. This is due to the weak understanding of legal apparatus so that they behave arbitrarily during criminal proceedings and view detainee as an object of examination. Meanwhile, $23.3 \%$ of respondents argued that torture against detainee caused by weak supervision especially by related chief of legal apparatus and other $11.4 \%$ respondents claimed that it was due to the limited facilities of law enforcement institutions.

Arrogance of legal apparatus confirmed by majority respondents as the main cause for torture against detainee is consistent with the cause for the weak coordination among legal officials. The arrogance exists due to the misunderstanding of some legal officials in the function and authority given by law. The function and authority were understood and interpreted as something personally inherent in each of legal officers. Consequently, detainee who juridically has equal position with the legal apparatus and rights not to be tortured is not viewed as a subject of examination, but as an object of examination in the criminal justice process.

Legal officers' arrogance which is most dominant factor leads to the torture against detainee, which is strongly correlated with the weak supervision claimed by $21.3 \%$ respondents. Weak supervision, either coming from the internal law enforcement institution or community and mass media will leave time that allow torture against detainee to happen.

A limited facility in the prison which is far from the standard was confirmed by $20.7 \%$ respondents, it was another factor to cause torture against detainees. Therefore, condition of facilities belong to institution responsible for detention should be clearly discussed. Factual condition of the facilities both at detention house and detention room are still below the standard to accomodate detainees. However, if both conditions are compared, the condition in detention house is far better than that in police station.

Based on the opinion of detainees and ex-detainees participated as respondent, 100\% respondents confessed that detention in detention house is far better than that of police station. Their argument is mostly true if viewed from the factual condition of detention room in police station as well as treatment to detainees. Condition of detention room in police station 
is still far away from the minimum standard for treatment to detainee both regulated in the national regulation and international Human Right instruments.

Carefully examine Rule 10 and 11 in minimum standard of United Nation about treatment to prisoners/detainees, it is clearly defined that detention room in police station and detention house in Indonesia are not comply with the minimum standard. In fact, minimum standard of United Standard about treatment to prisoners and detainees have 55 rules added with 5 special categories. Lack in facility clearly seen in detention rooms of police station starting from capacity, accommodation, health and food service. Similarly the case with detention house having limited facilities especially unstandardized capacity with the increasing number of prisoners.

\section{Conclusions}

The following conclusions are drawn based on the results of the study:

The implementation of suspect rights to freedom from torture and cruel treatment during the detention process had not been optimally realized yet. The physical and non-physical (mental) torture practices against detainees and inhumane treatment in the from of persecution (battering) or placing detainee in narrow detention room which do not meet minimum standard of environmental health and mixing between child detainee and adult detainee were found.

The main obstacles in the practice for effective implementation of rights not to be tortured and cruelly treated during detention process are the weak understanding of legal officials about law instruments against torture and arrogance of some of the legal officials viewing detainees as objects of examination, and the understanding of the principle of due process law is still deliberately low especially during inquiry and investigation.

\section{Suggestions}

To implement rights of suspect to freedom from torture and cruel treatment during detention process, it is suggested to:

- increase the professionalism of law enforcement apparatus especially investigators , detention house officials and related prisons with law instruments against torture and other inhuman acts towards the accused facing detention.

- build detention house in every regency/city with standard facilities including maximum standard security so it can function well.

\section{References}

Achmad, A. (2005), Deterioration of Law in Indonesia (Causes and Solutions) Ghalia Indonesia, Jakarta.

Baerhr, \& Peter, R. (1998). Human Rights in Foreign Policy. Translation of Somardi from The Rule of Human Rights in Foreign Policy, Yayasan Obor Indonesia, Jakarta. 
Bellisario, D. L. (1992). Exciting action show [Television series]. Hollywood: American Broadcasting Company.

Cassesse, A. (1994). Human Rights in a Changing World. Yayasan Obor, Jakarta.

Constitution of the Republic of Indonesia Year. (1945). UUD NRI 1945.

Davidson, S. (1993). Human Rights. Open University Press, Buckingham.

DeRover, C. (2000). To Serve and To Protect: Acuan Universal Penegakan HAM. Translate by Supardan Mansyur, PT. Radjagrafindo Persada, Jakarta.

EI-Muhtaj, M. (2005). Human Rights in the Constitution of Indonesia. Prenada Media, Jakarta.

Fakih, M. (2003). Enforcing Justice and Humanity: Handbook for Building a Movement for Human Rights. INSIT Press, Yogyakarta.

Government Regulation No. 27 Year 1983 on the implementation of Law No. 8 of 1981 About the Book of the Law of Criminal Procedure.

Haryanto, I. (2000). International Covenant on Civil and Political Rights, Institute for Press and Development Studies. Jakarta.

Important, I. M. (1990, November 1). The nightly news hour [Television broadcast]. New York, NY: Central Broadcasting Service.

Law of the Republic of Indonesia Number. 8 on 1981, on the Book of the Law of Criminal Procedure (KUHAP).

Law of the Republic of Indonesia Number 12 Year 1995 on Correctional.

Law of the Republic of Indonesia Number 3 Year 1997 on Juvenile Justice

Law of the Republic of Indonesia Number 39 Year 1999 on Human Rights.

Law of the Republic of Indonesia Number 26 Year 2000 on Human Rights Court.

Marzuki, P. M. (2005). Legal Research. Kencana Prenada Media Group, Jakarta.

Muladi. (2003). Human Rights (Nature, Concepts and Implications In Community Perspective). Rafika Aditama, Bandung.

Nembrini, P. G. (2007). Prison environment. Translation By ICRC Delelegasi Indonesia.

Nickel, \& James, W. (1996). Human Rights (Philosophical Reflections On Universal Declaration of Human Rights). Translation by Titis Eddy Arini, PT. Gramedia Pustaka Utama, Jakarta.

Pax, B., \& Mahendra. (2000). Convention against Torture. Institute for Press and Development Studies, Jakarta. 


\section{Macrothink}

International Journal of Social Science Research

ISSN 2327-5510

2014, Vol. 2, No. 1

Parker-Pope, T. (2008, May 6). Psychiatry handbook linked to drug industry. The New York Times. Retrieved from http://www.nytimes.com

\section{Copyright Disclaimer}

Copyright reserved by the author(s).

This article is an open-access article distributed under the terms and conditions of the Creative Commons Attribution license (http://creativecommons.org/licenses/by/3.0/). 